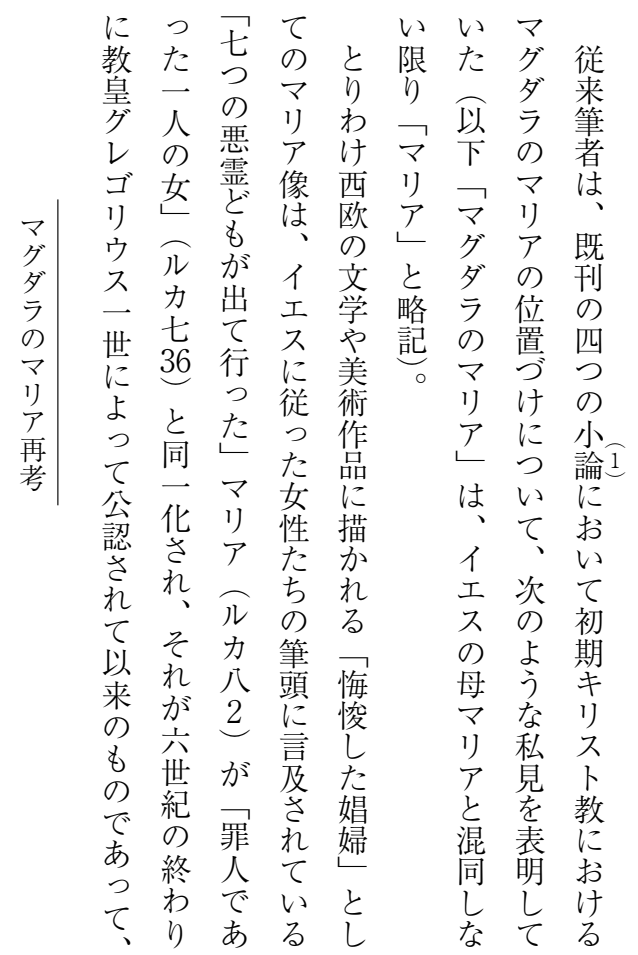

は
に

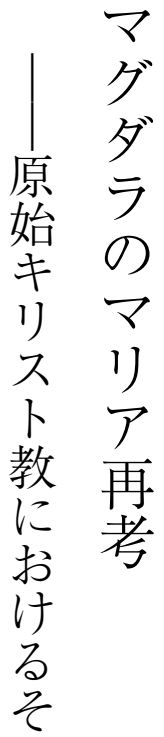

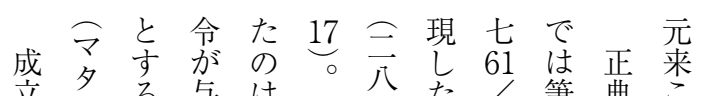

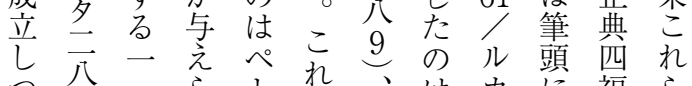

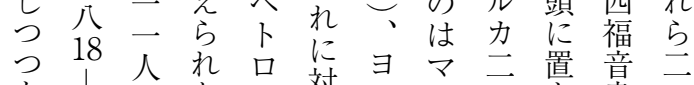

あ 20 のたに対公四杂意う

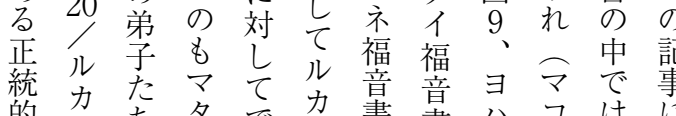

的云ち名で福書書 公 二

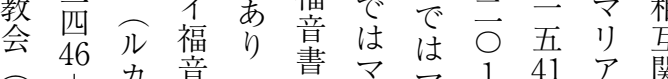
初| カ 竟 49 で書 三

力使は光四、、ア ア 照マ少少な

会年姑

員月

芒旦

の

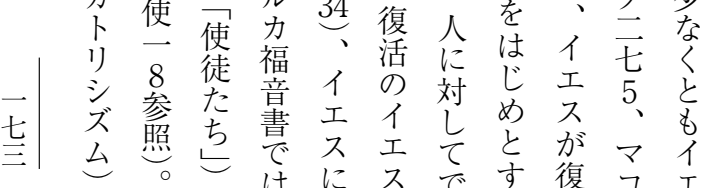

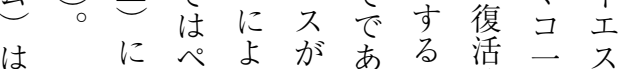

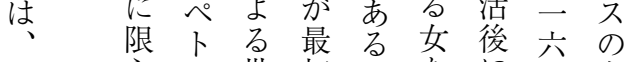

マら口世初こたに1女

夕机を界に二ち最/弟

献

イては宣顕 $○$ で初マ年

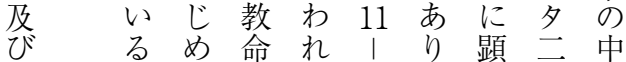




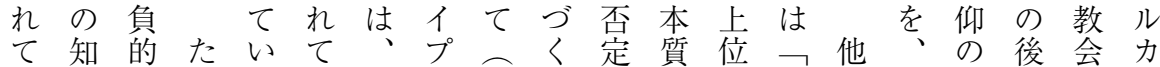
心患側たる拉例と不本定基覚方乃゙基継に福

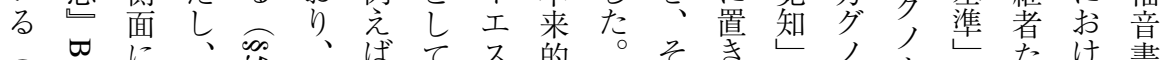
求

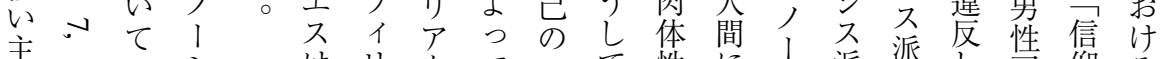

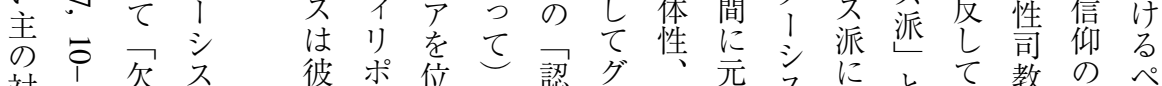

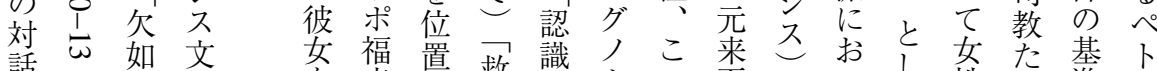

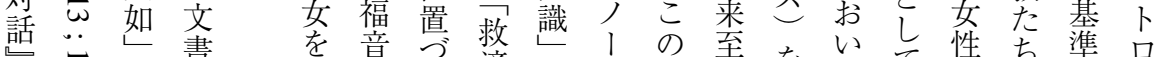

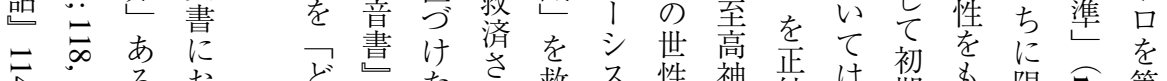

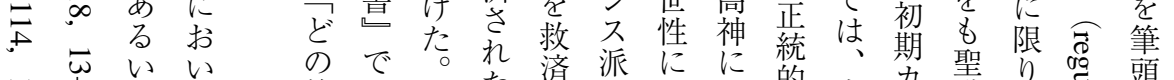

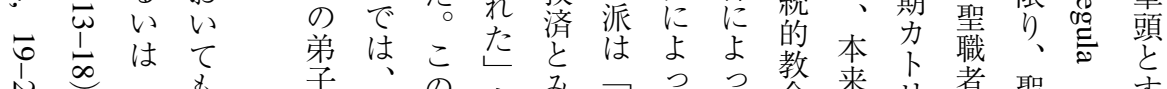
气

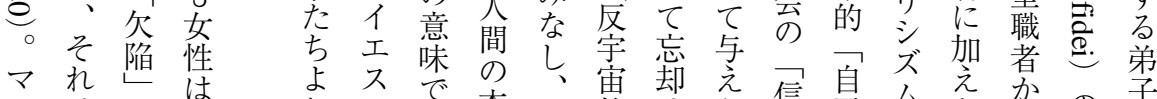

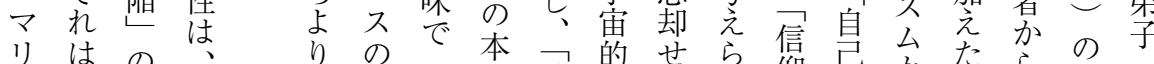

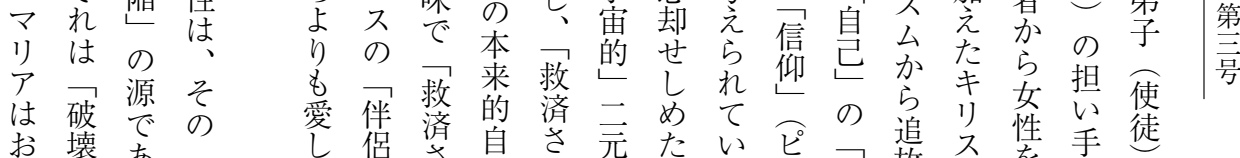

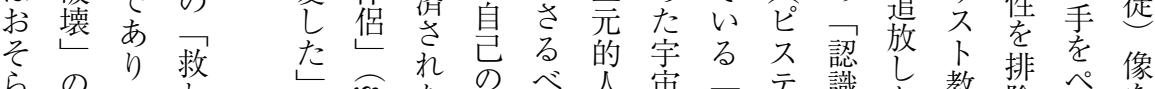

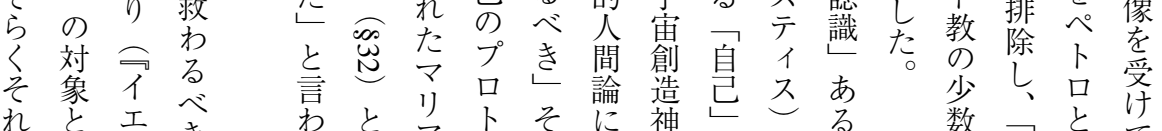

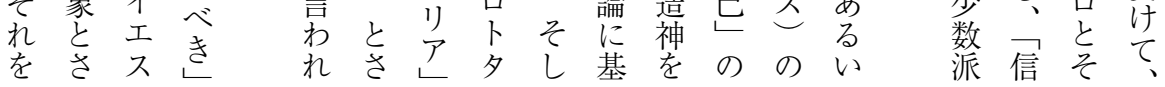

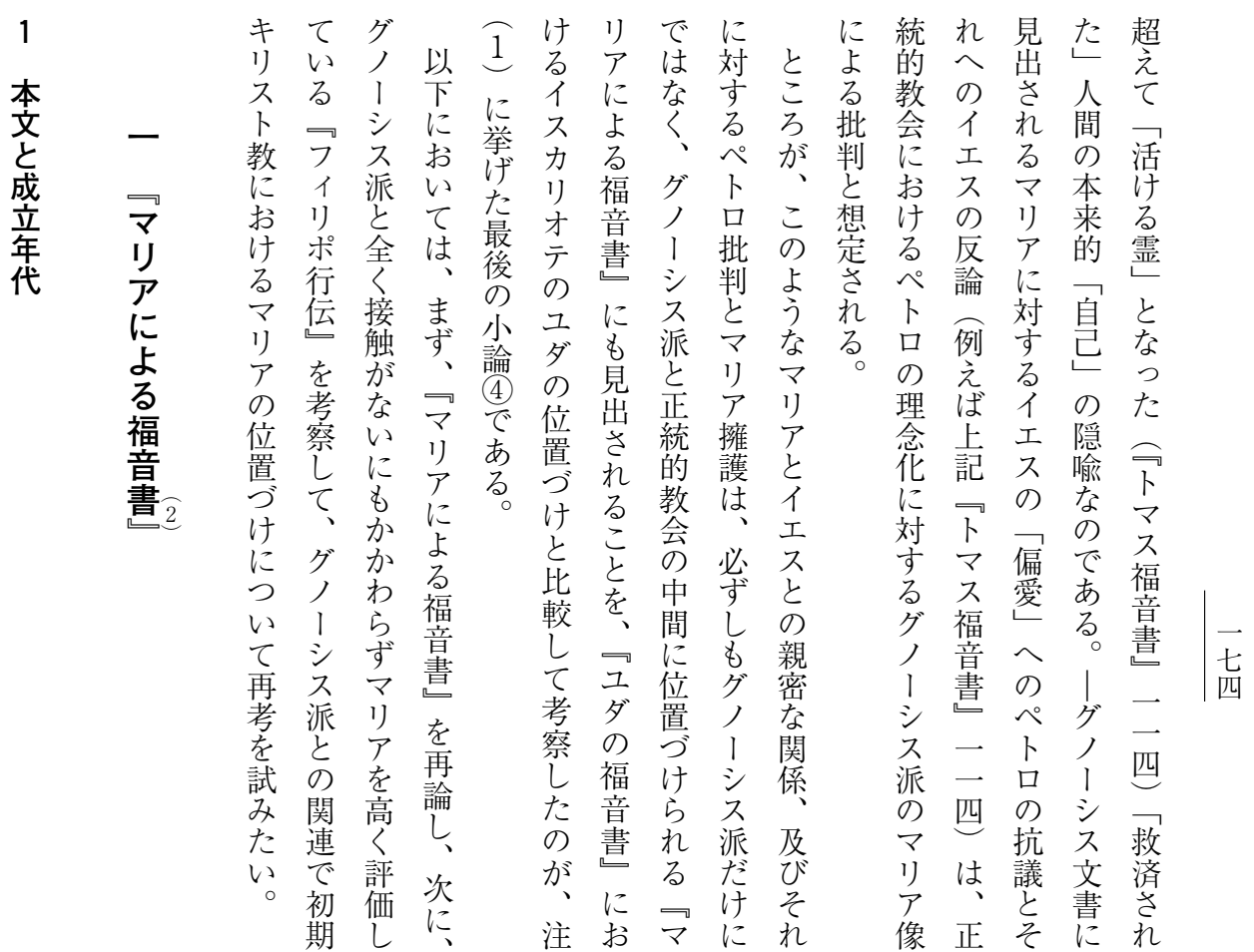




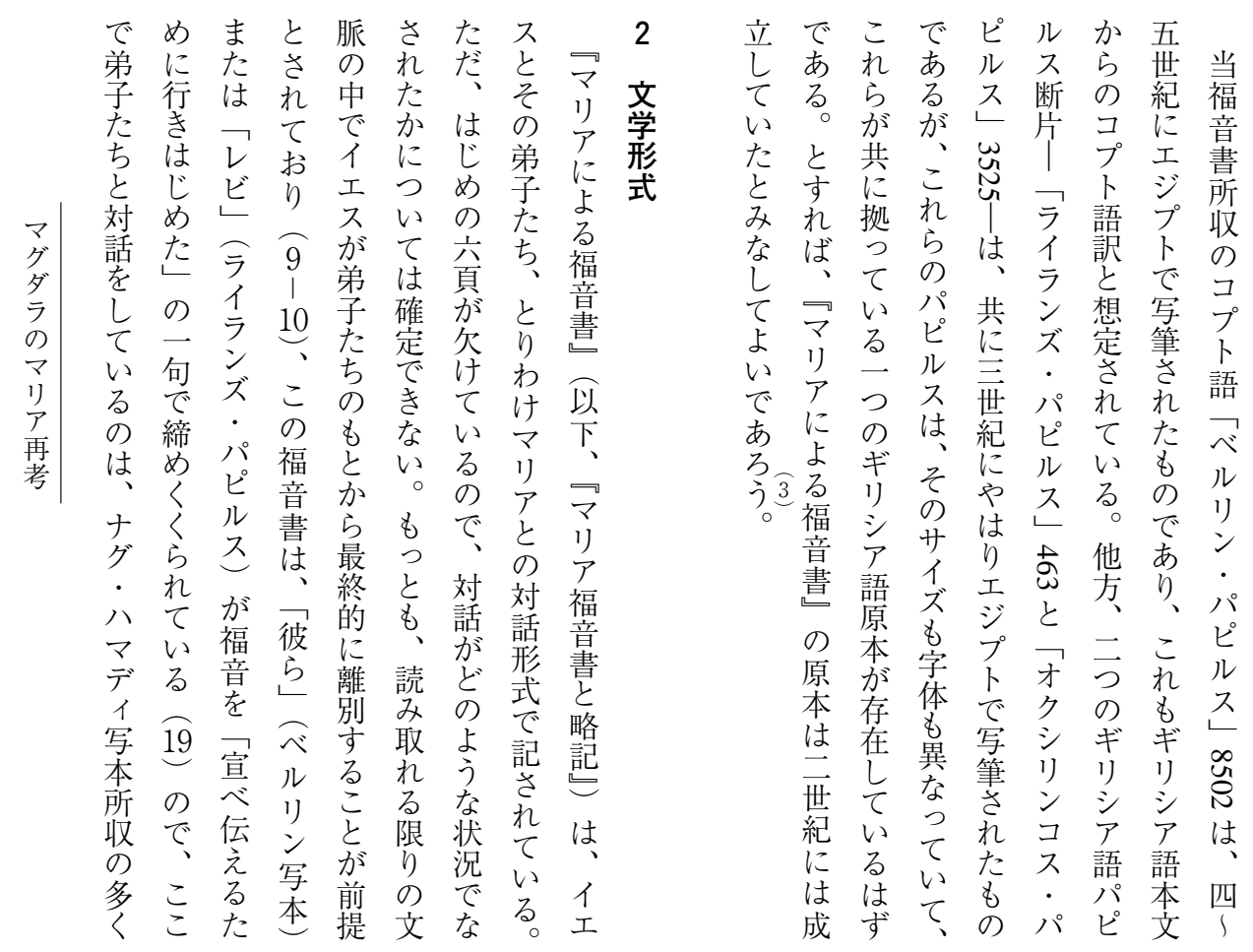

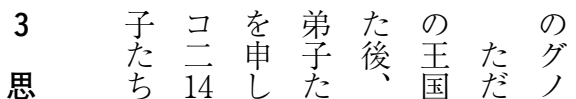

思想参立ち弟のしl

的照元に福こ

特たがる彼た音の不

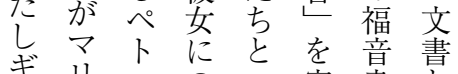

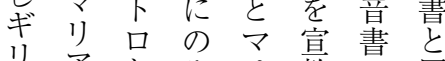

りアとみリ教 㝵同

学を勇顕ア势主様

語擁シ篗どさるた

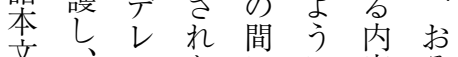

文是たにに容そ

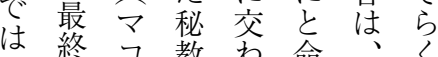

々的言老さじイ復

ビは $\overrightarrow{16}$ 語れて、㗍

彼 18 が対弟がの

宣告々照そ話子晜 イ

教 れあちたス

におににるのちで

赴之対。甩にあ

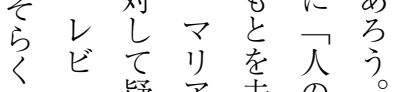

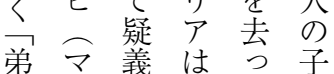




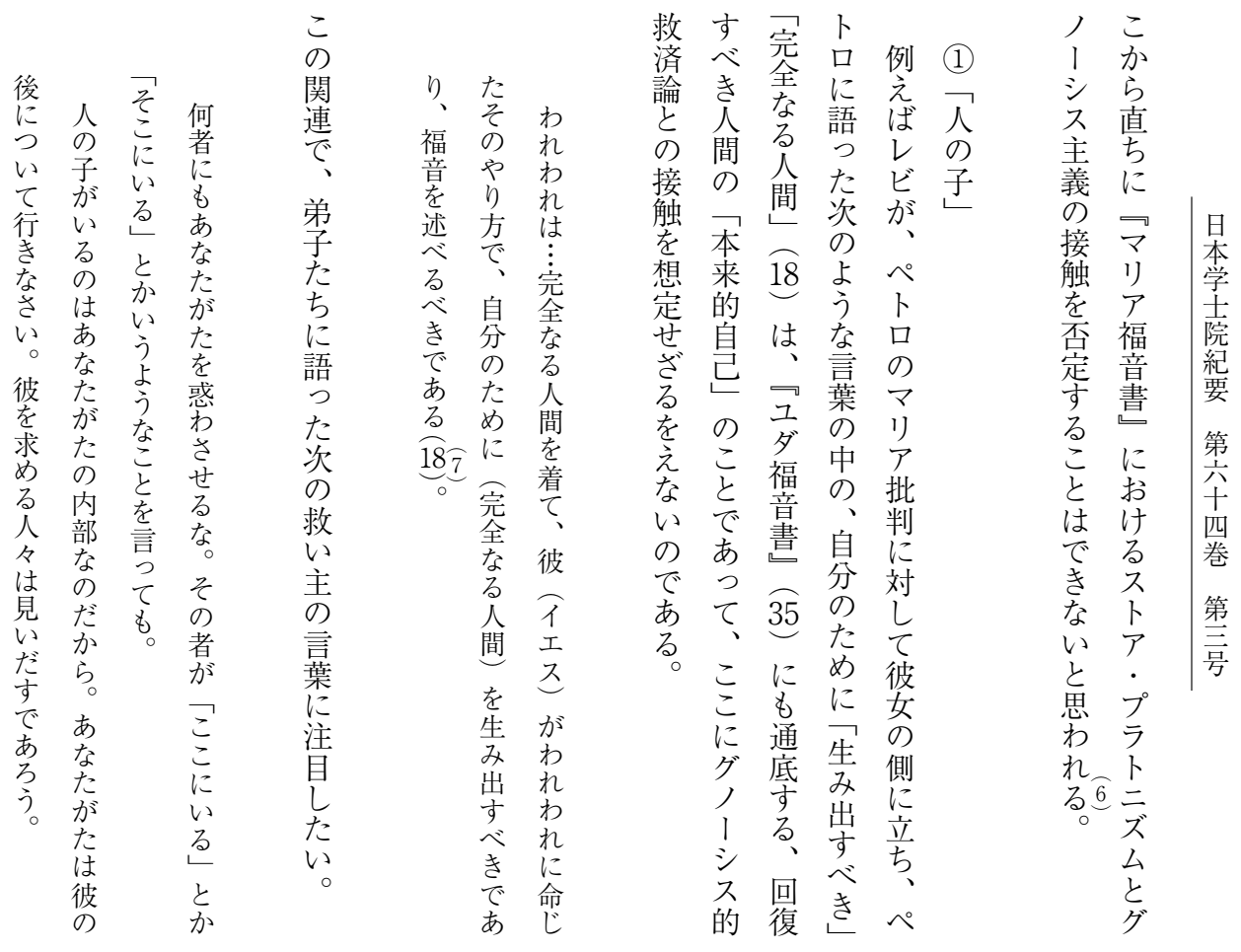

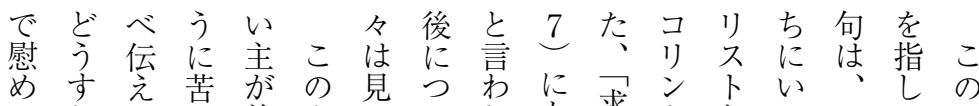

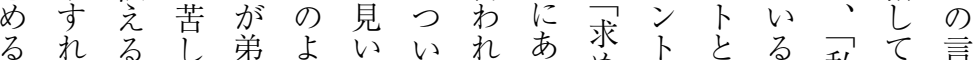

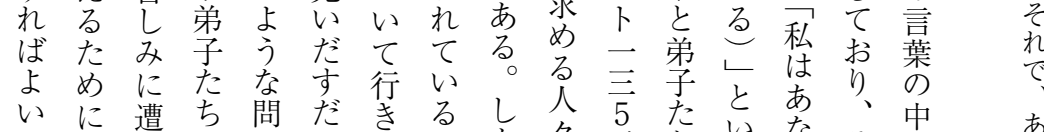

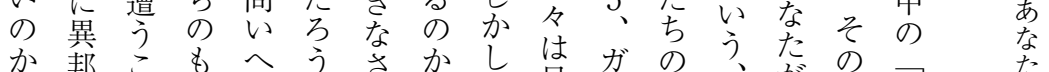

か 邦 こ

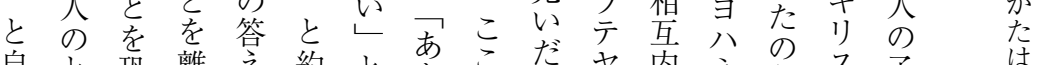

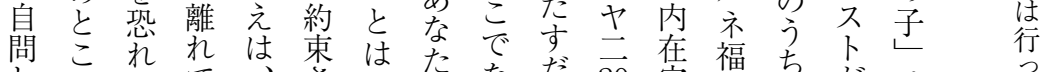

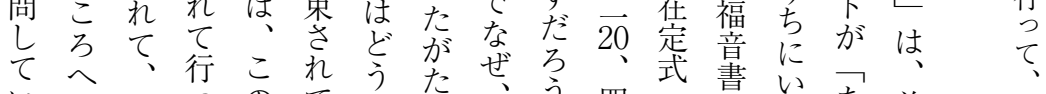

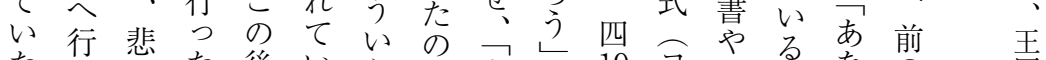

たく時くた 後い う 内 キ

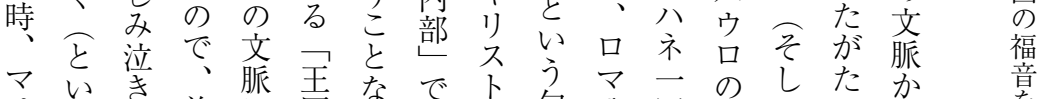

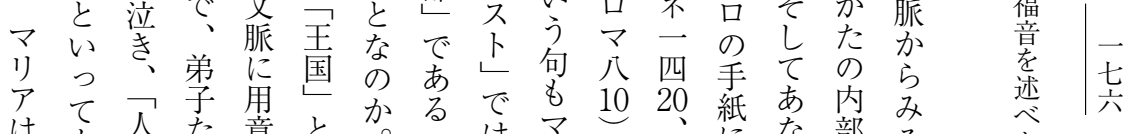

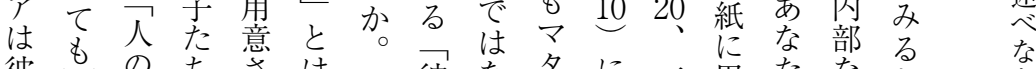

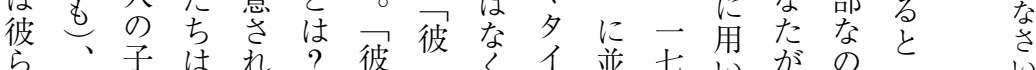

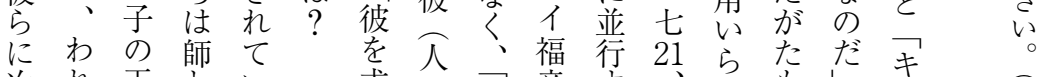

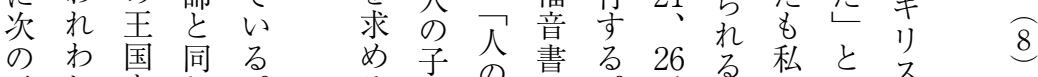

言葉は 


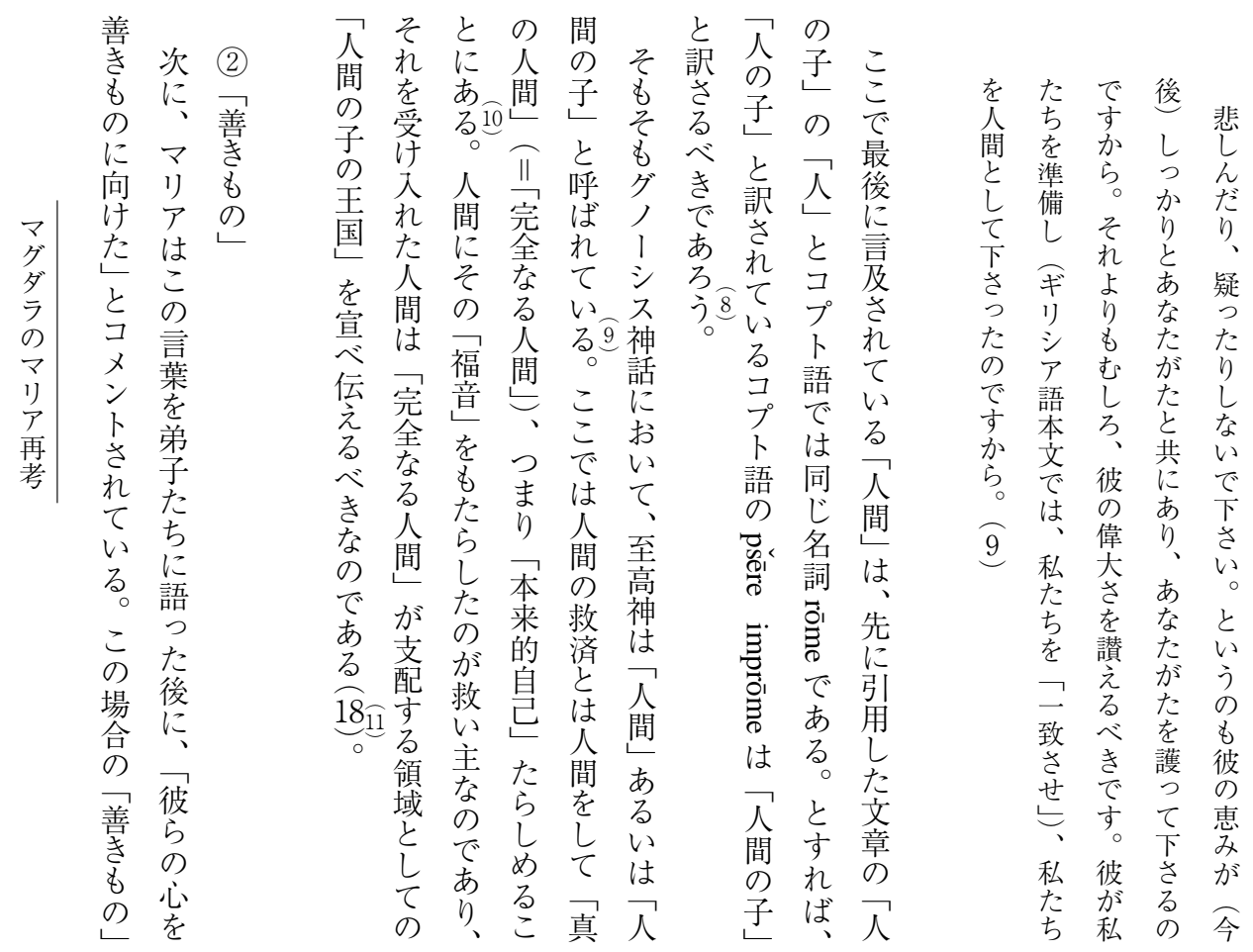

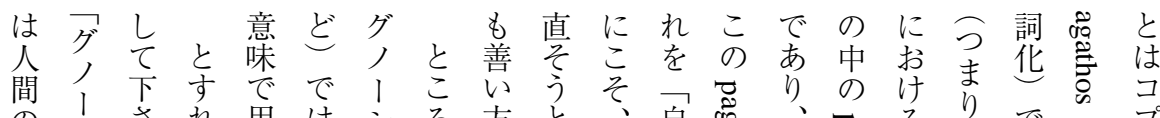

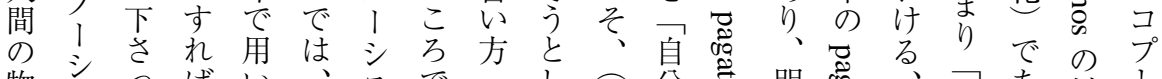

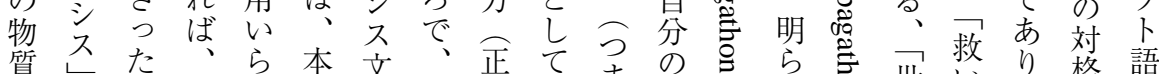
質々たた、

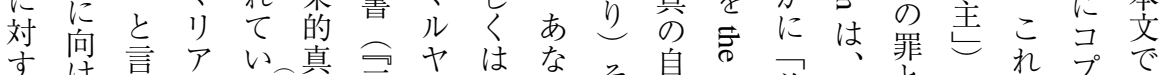

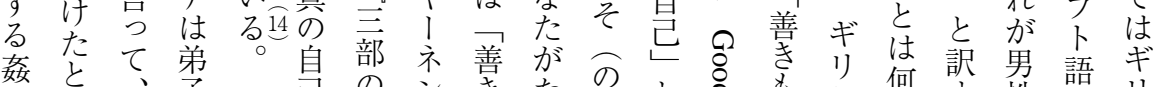

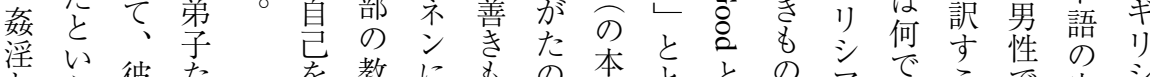

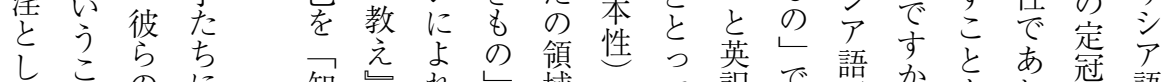

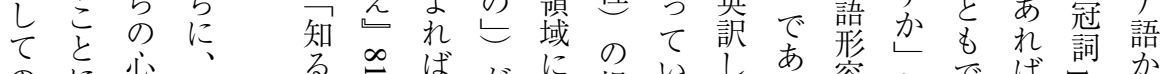

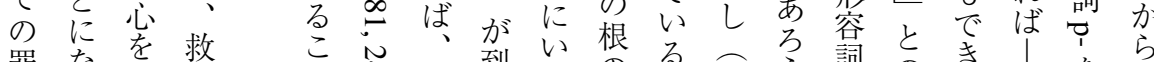

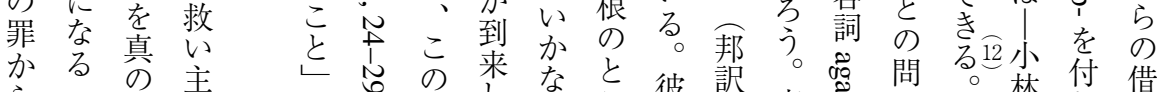

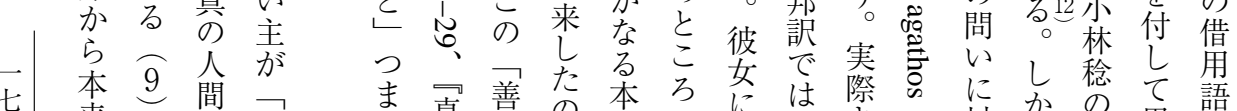

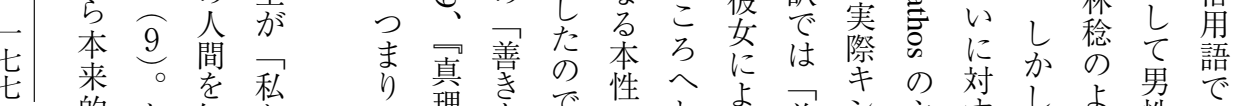

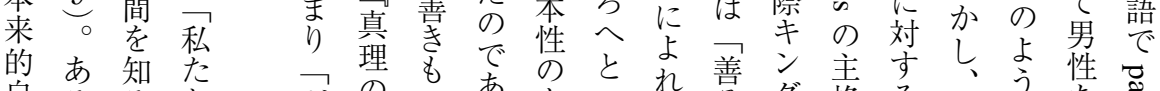

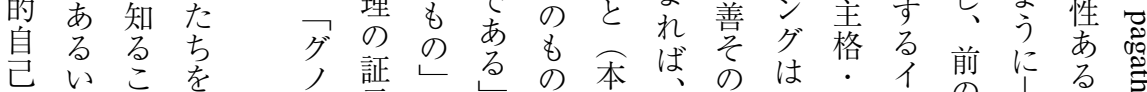

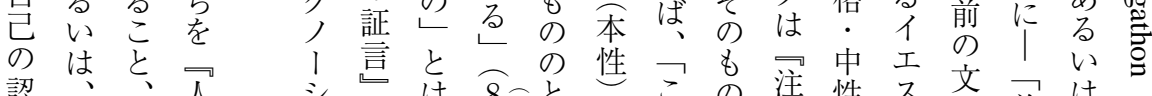

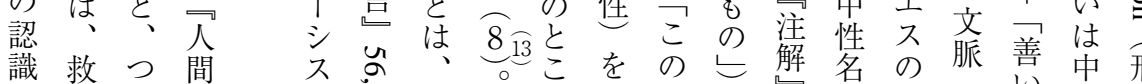

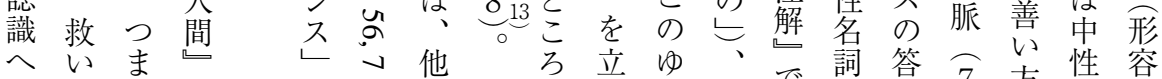

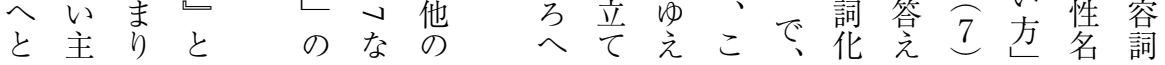




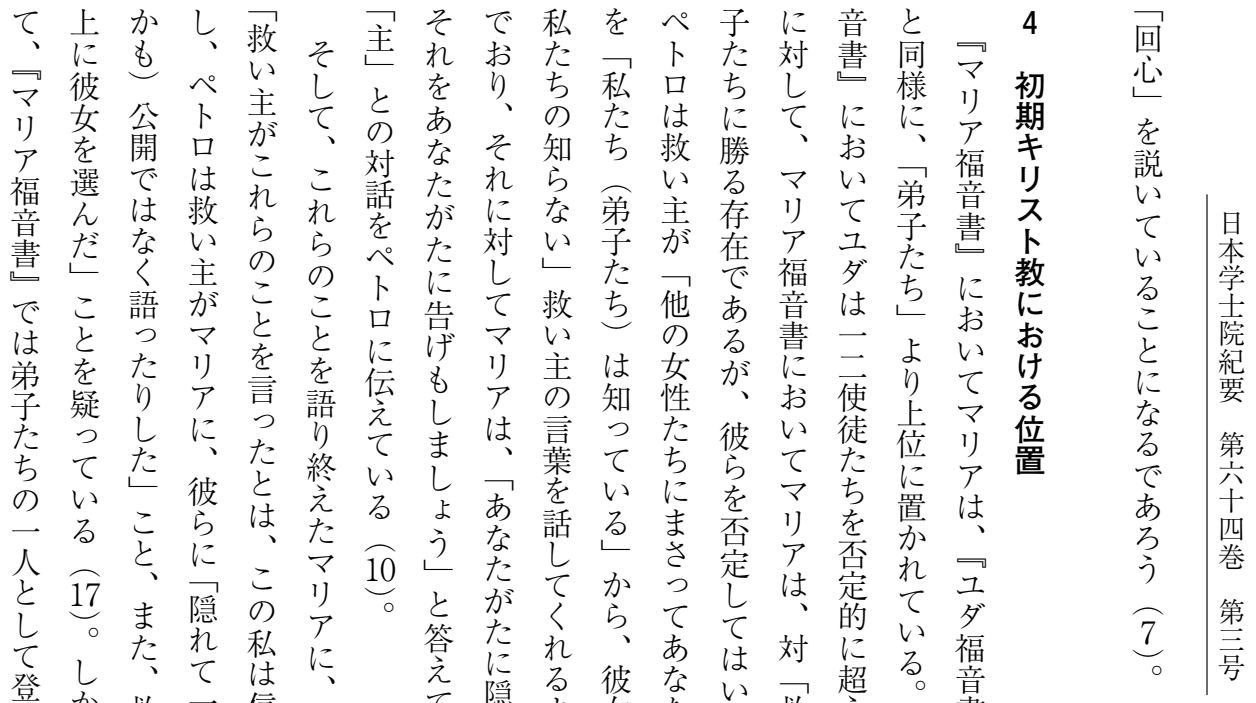

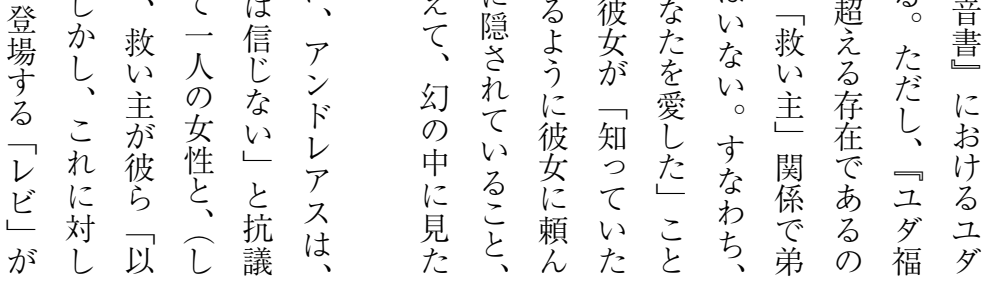

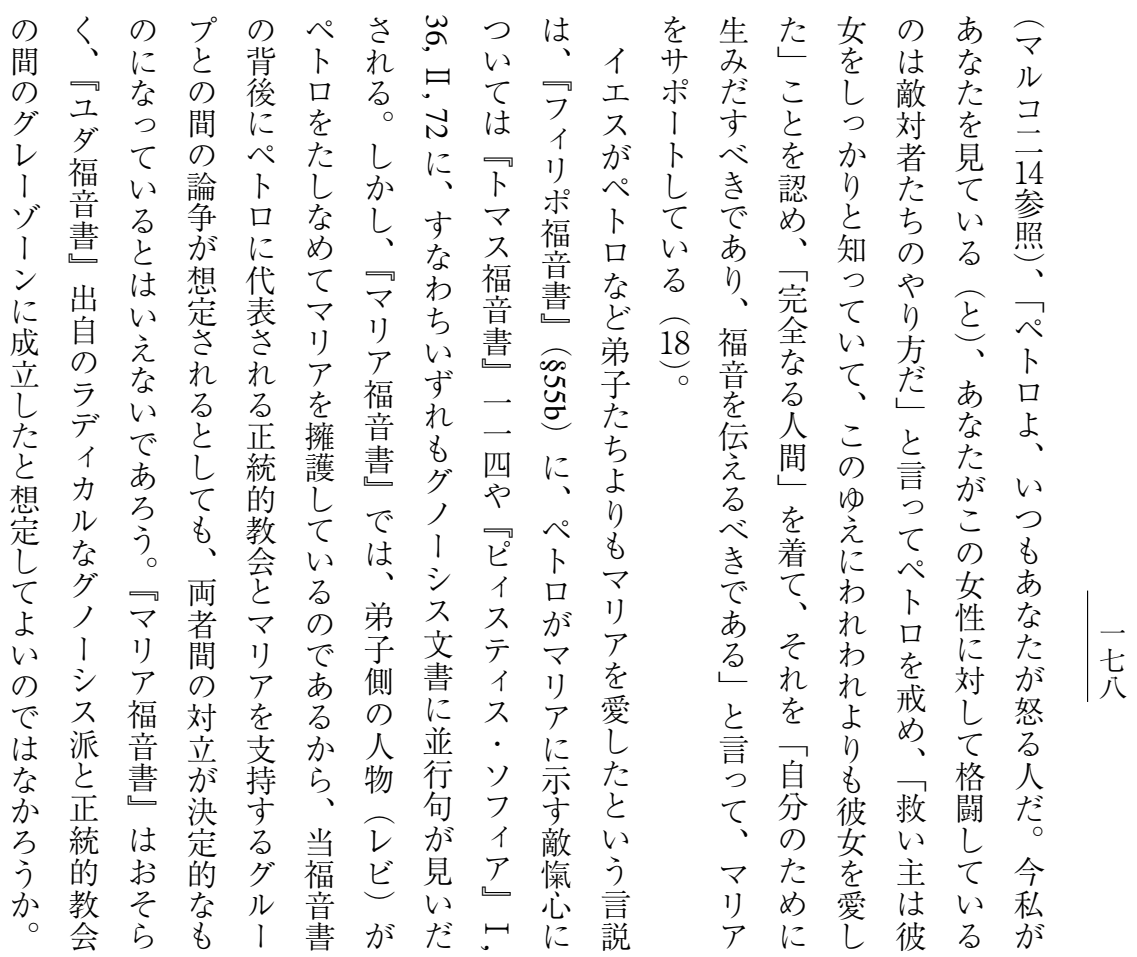




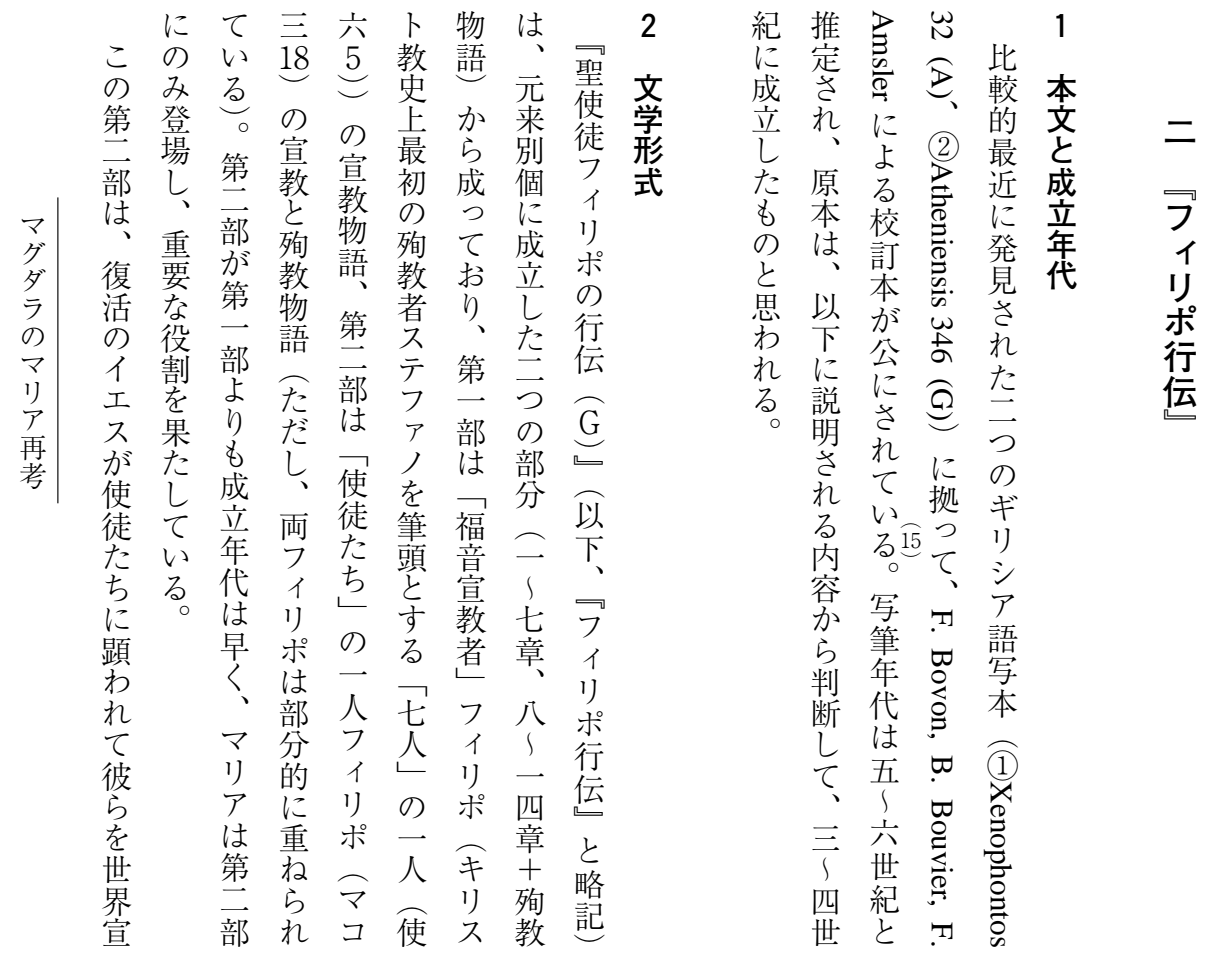

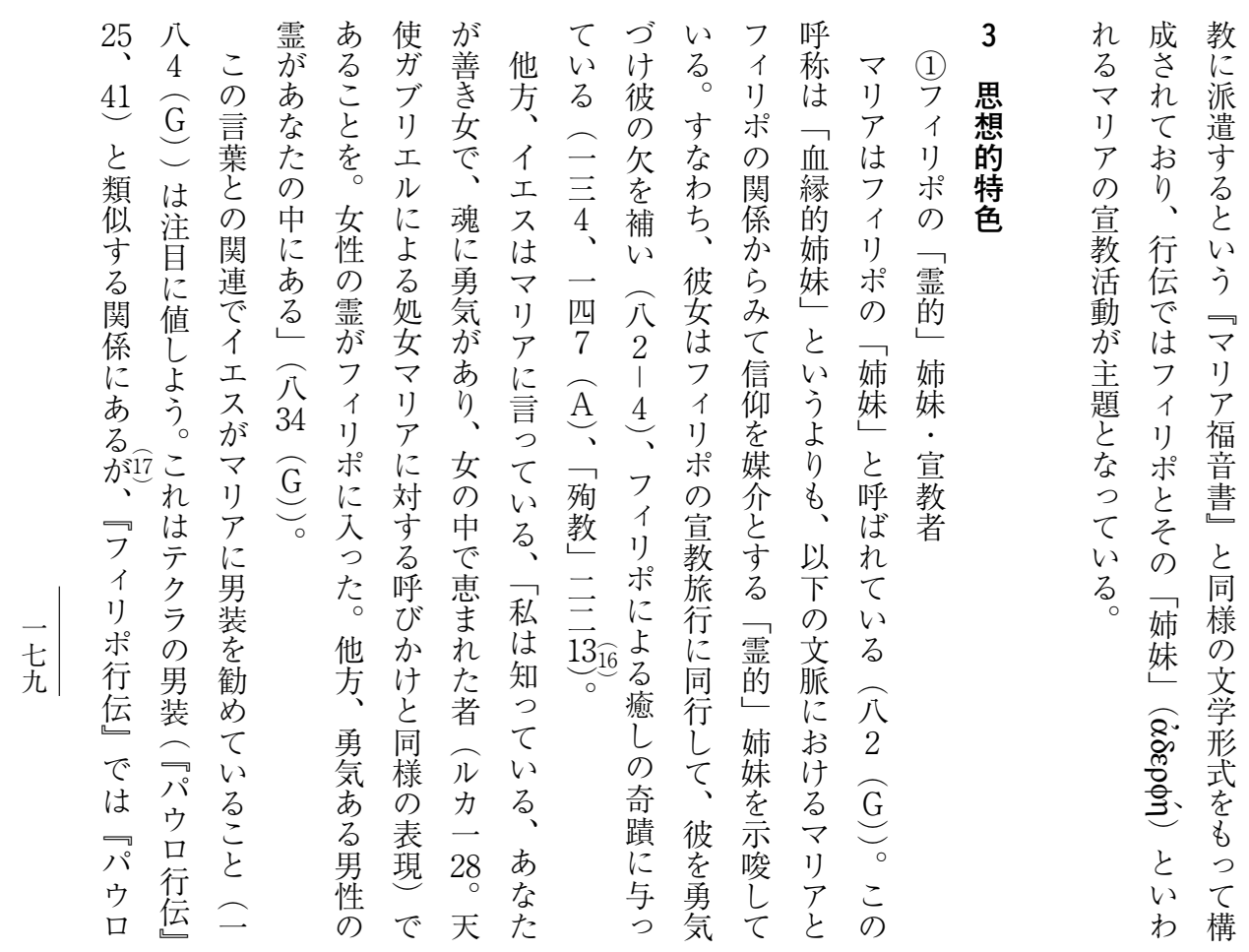




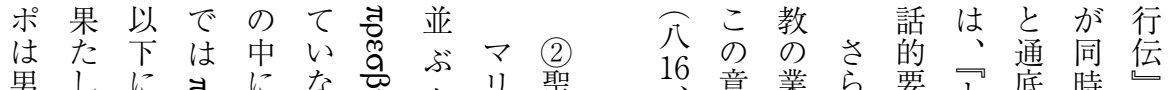

男しに

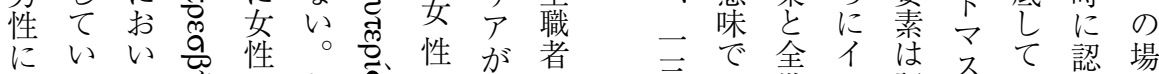

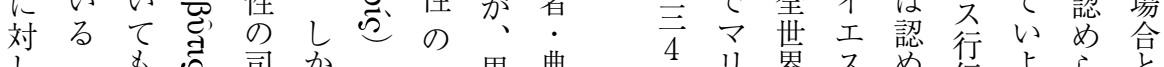

て 八

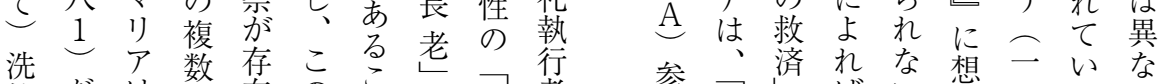

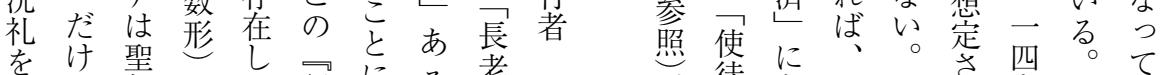

執で餐にて行にる老

行はな゚䄈よ伝ついあ

てくな゙パ く

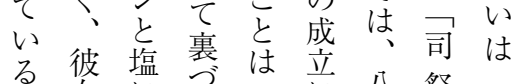

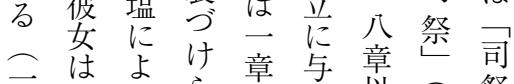

四文 る

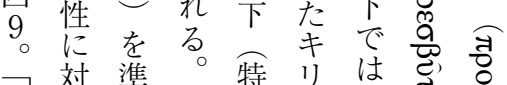

殉し 対準し 特 リ

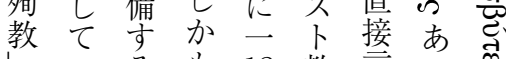

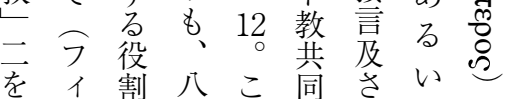

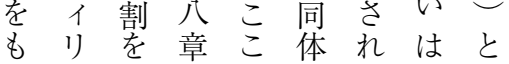

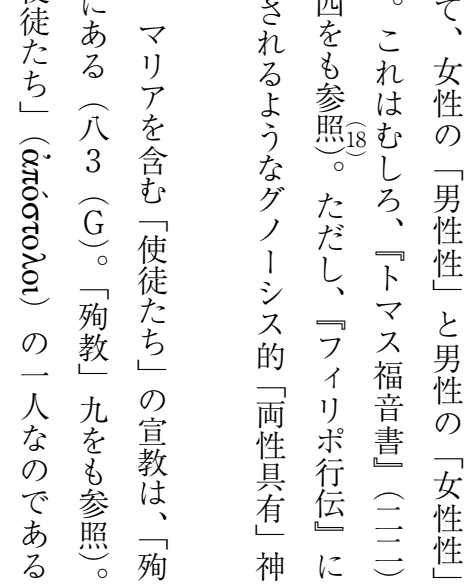

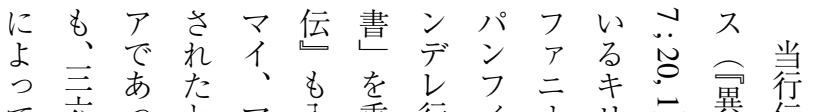

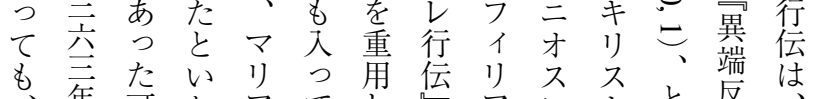

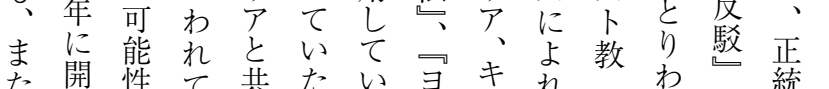

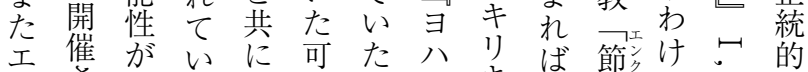

ピさ れるる

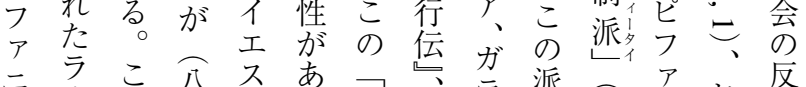

オ オ

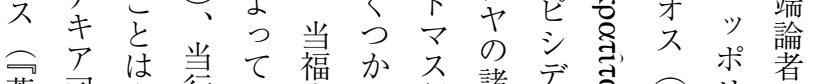

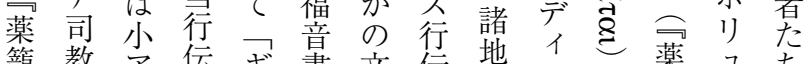

籠 教ア 伝 ギ書 文伝方ア、出籠 地ち

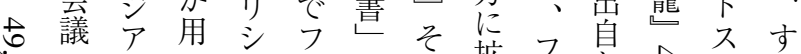

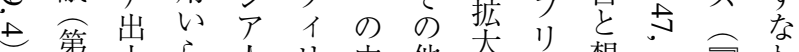

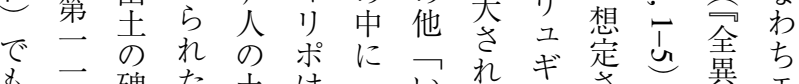

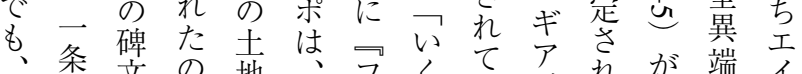

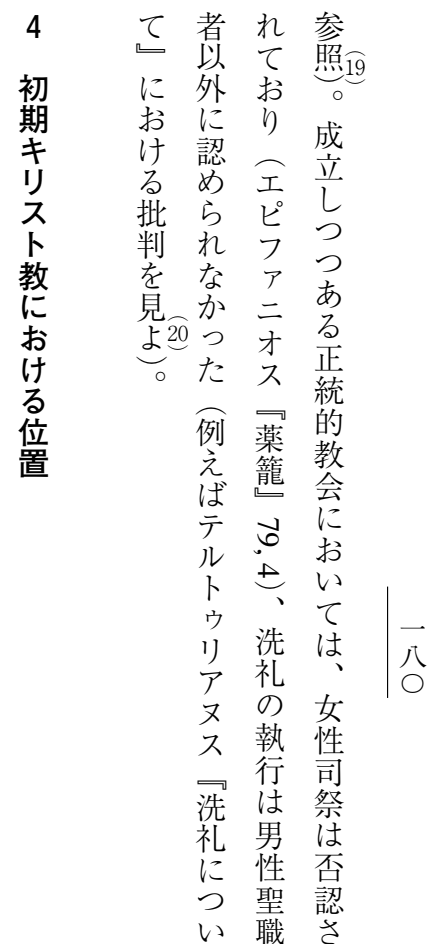

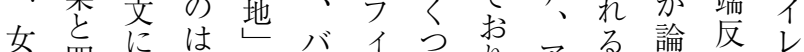

性四よ小にルリかり、ア 西駁駁ナ

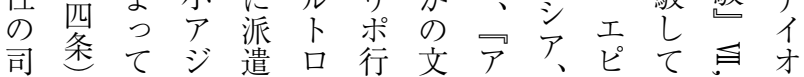



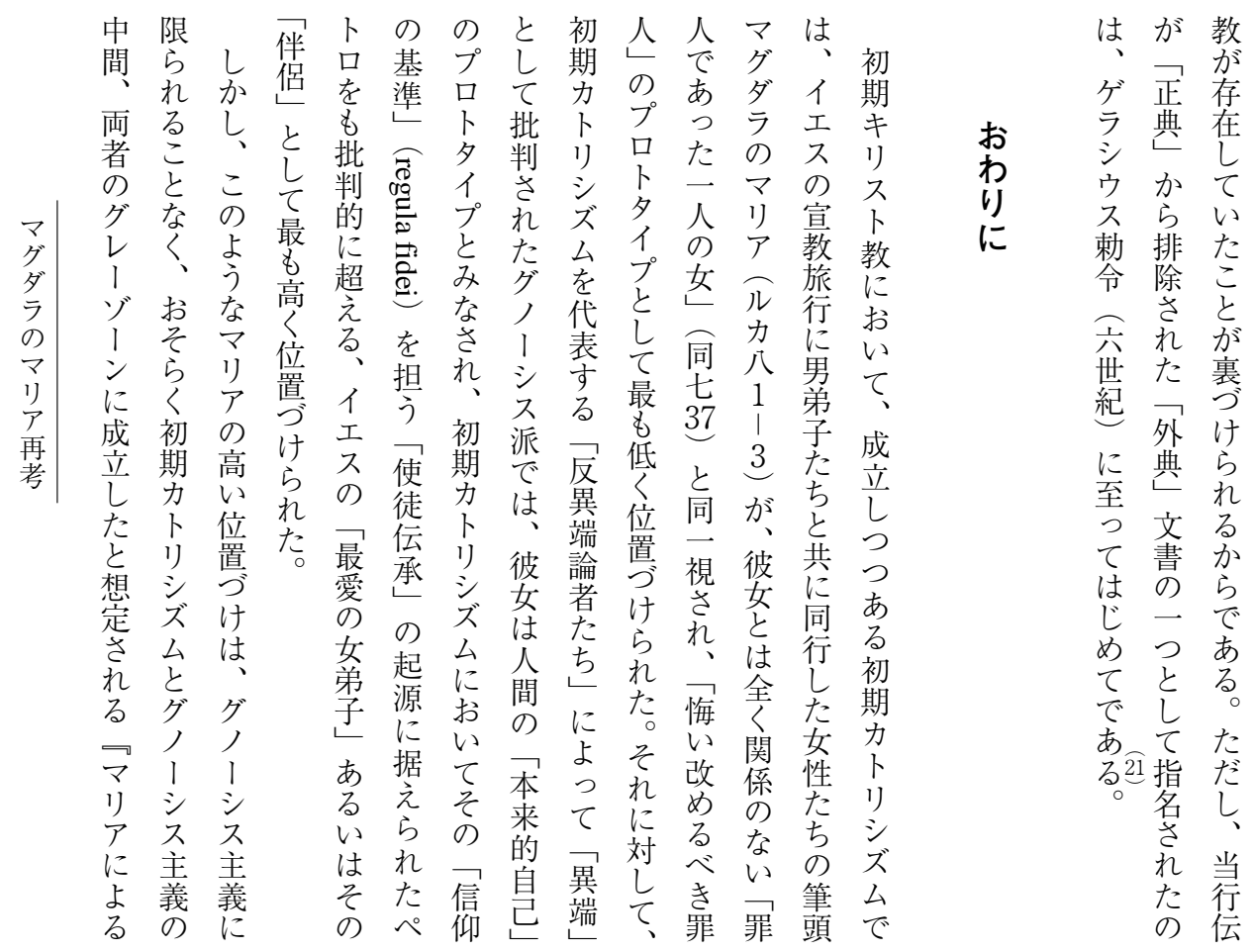

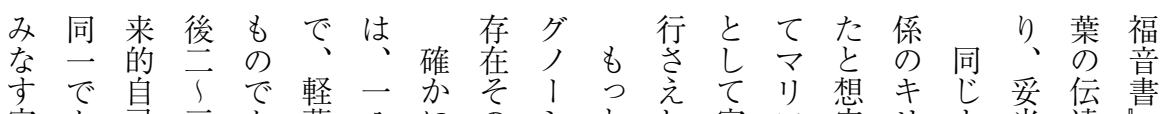

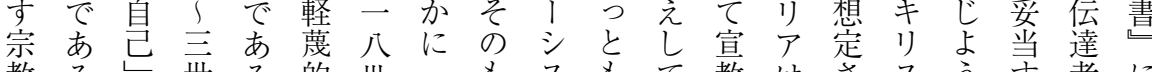

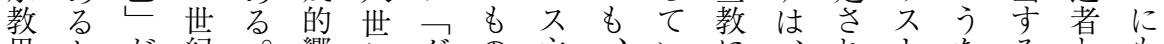
思とが紀。響紀グの主、いにによ的なる 想いで に し き キ、本け ワ反質るキ、づて ス

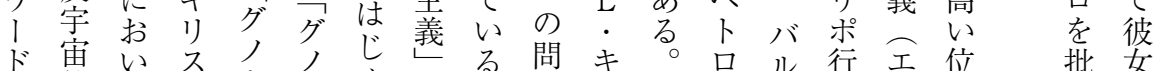

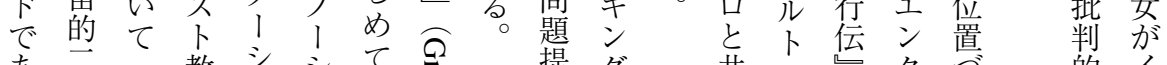

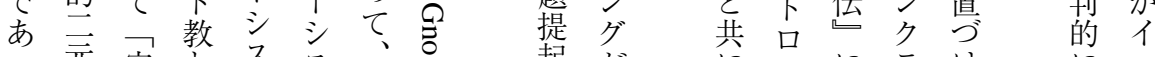

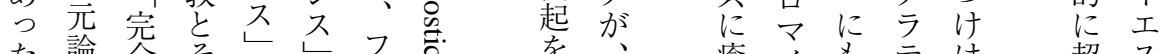

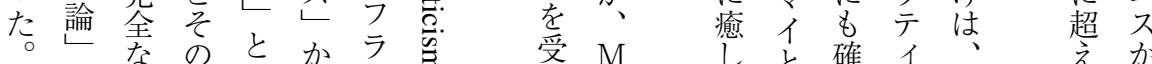

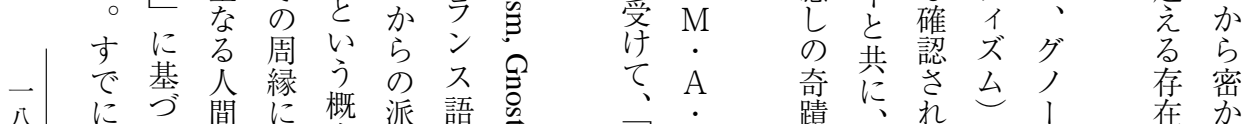
八にづ間に概派語导等 会涩と 畫認 し

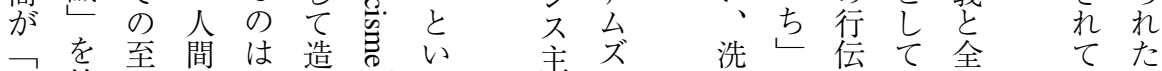

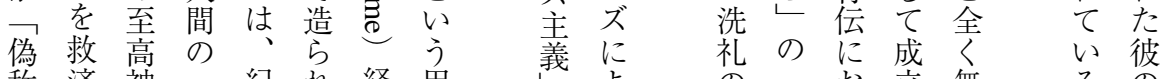

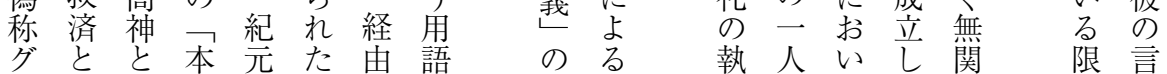




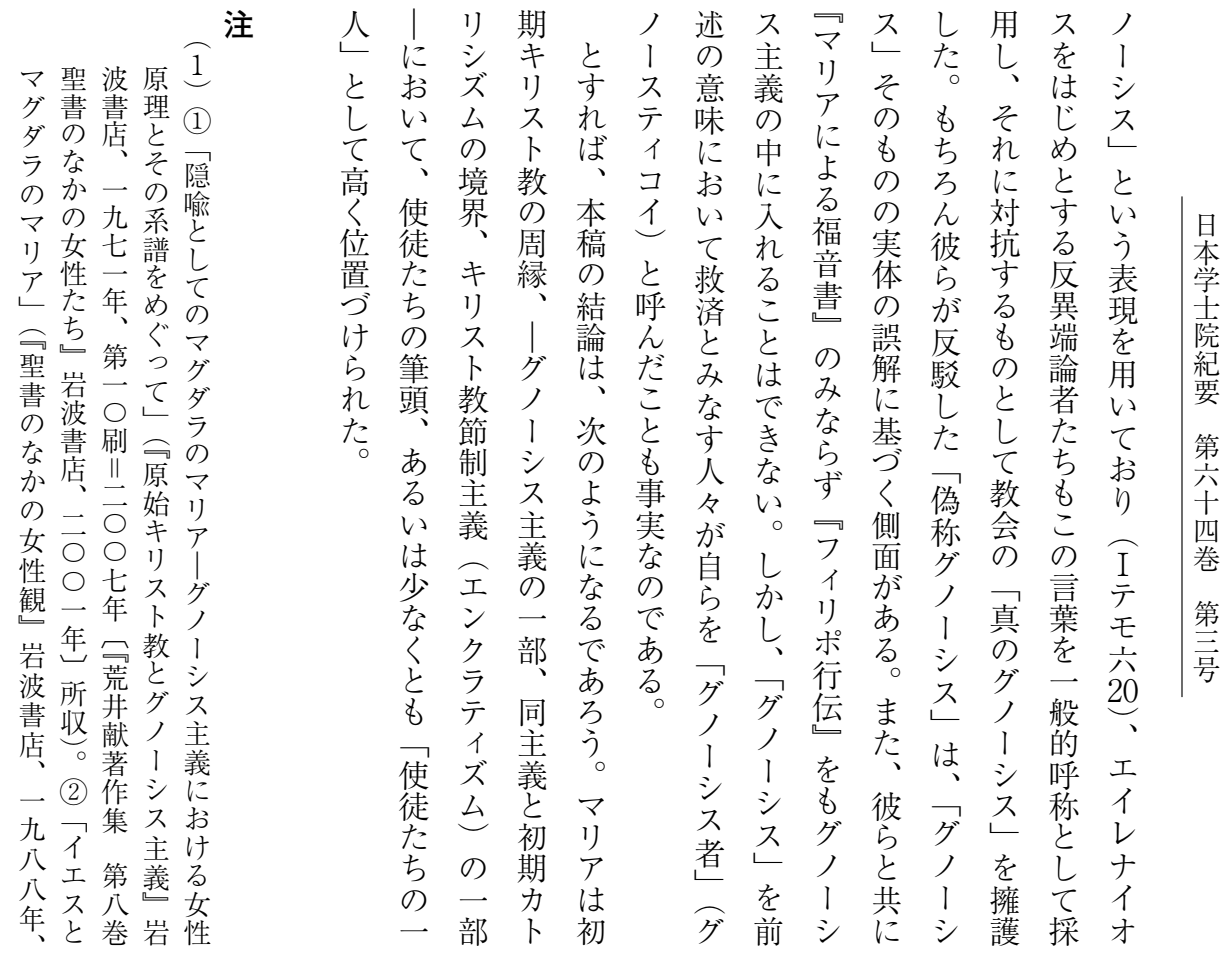

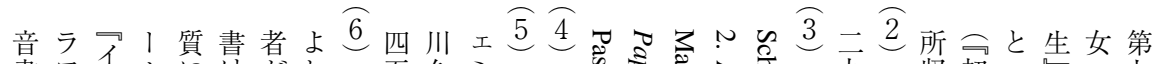

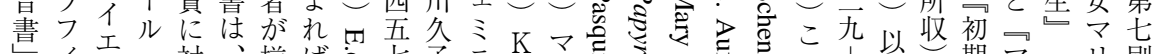

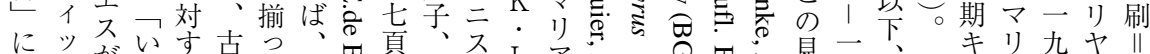

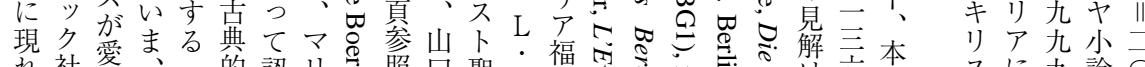

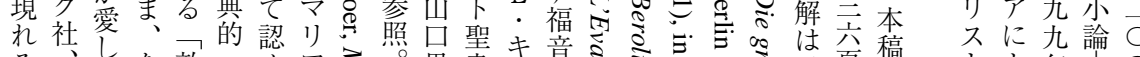

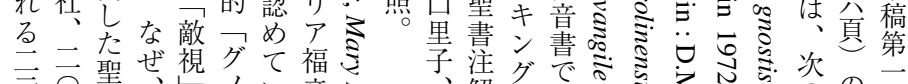

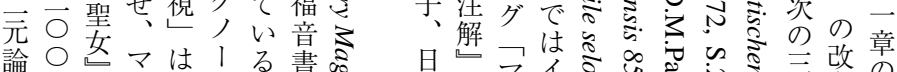

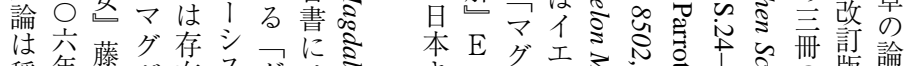

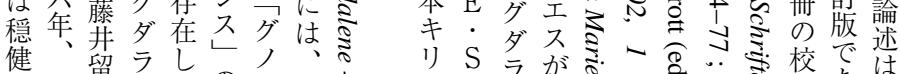
な二美のな特当尚

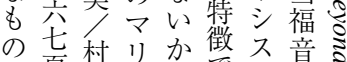
で頁榃アらで主書 グ私綾なでる義の校 グ想尒のある訳る校恶 l見訳かる今思訂

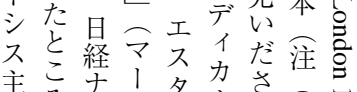

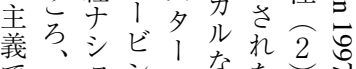
で弓ョコ． なな はマナ・A $\mathrm{A}$ 示参す なリルマ・論当照安 くアジイデ辈当当の亮 ユ福グ、ブ物音編に

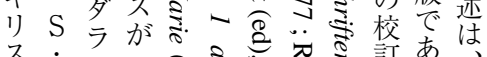

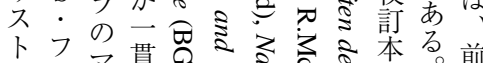

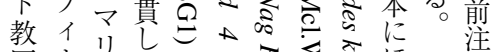

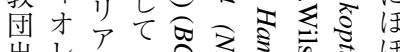

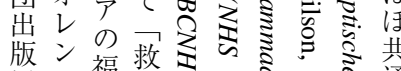
版シ福救过的高共

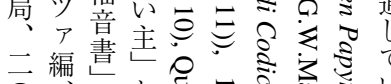

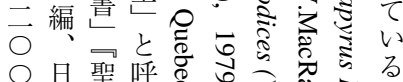

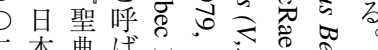

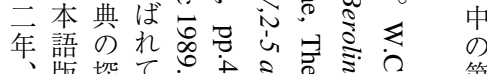

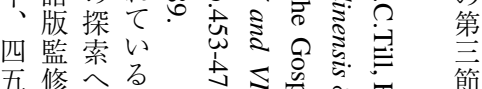
卜よ年|○ 教当只六 の福前遊年 霊音掲女前 性書荒説揭 宣|井の品 教原献起荒 - 始著源井 女キ作に献 性り集よ著 - ス造せ作 異卜所て集 端教所 ᄂ に聚聖所 岩扮。聖收 書る年。 店々马な (3) 二位多のマ ○置 福差方 竞別ダ

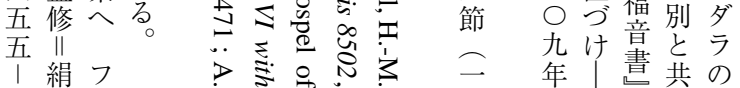




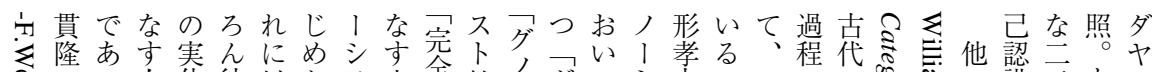

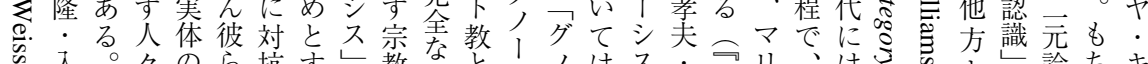

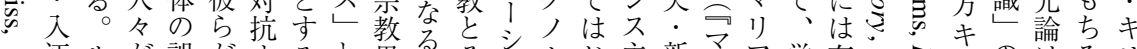

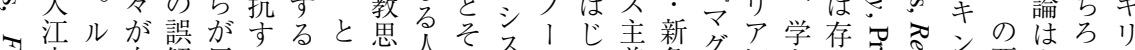

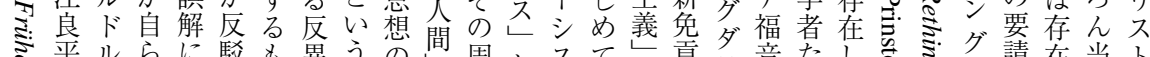

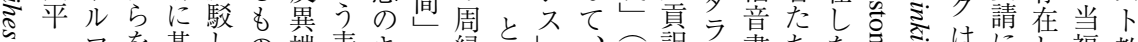

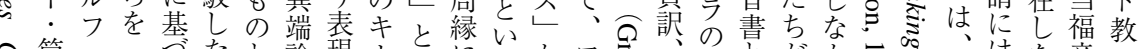

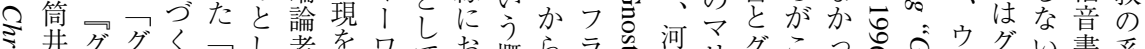

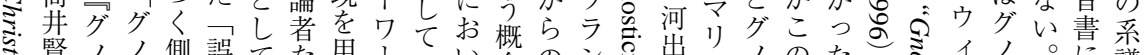

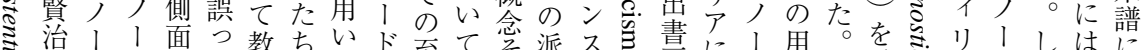

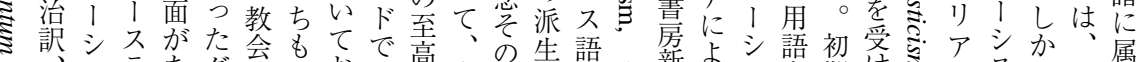

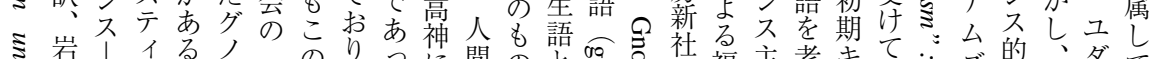

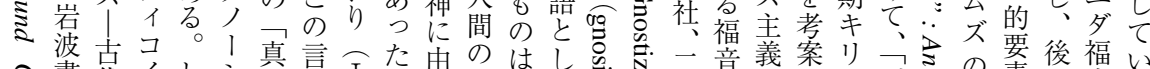

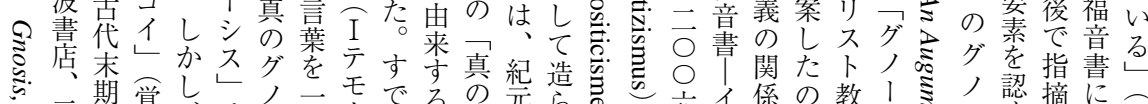

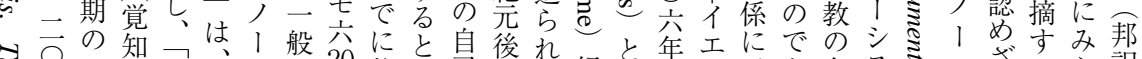

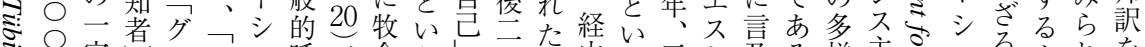

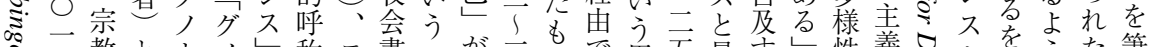

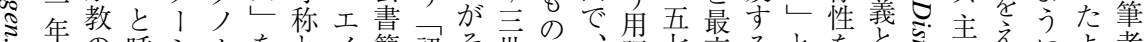

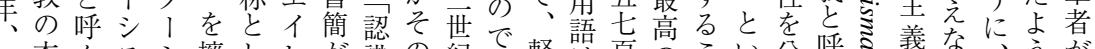
五本んスシ擁しレが識の紀あ軽は頁のこい分呼ミ我ないうが

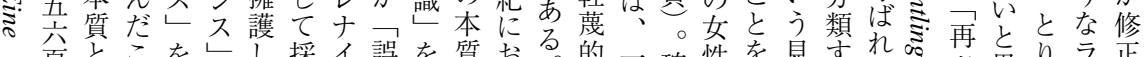

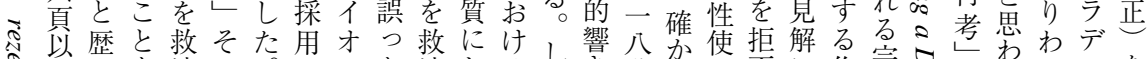

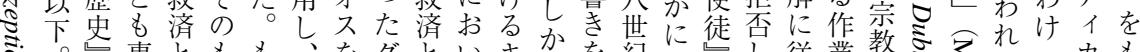

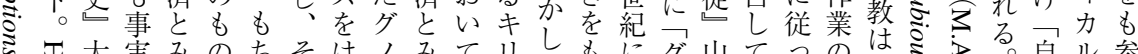

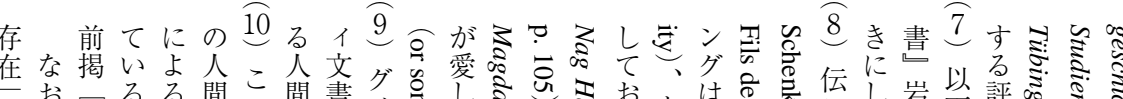

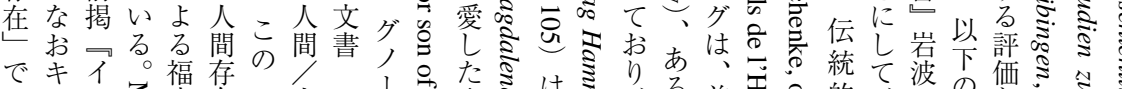

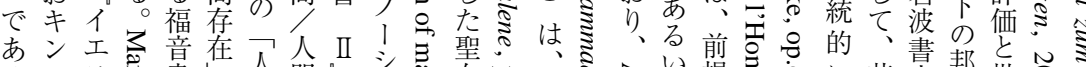

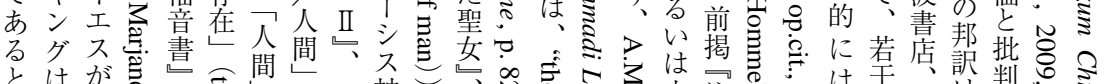

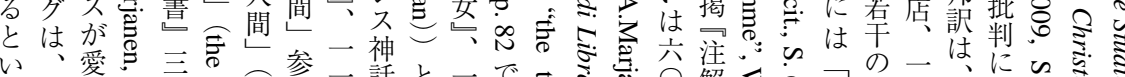

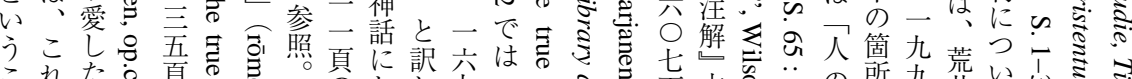

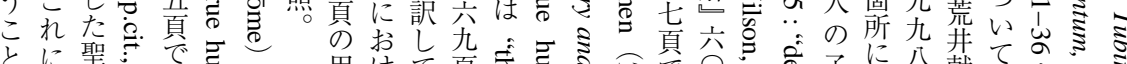

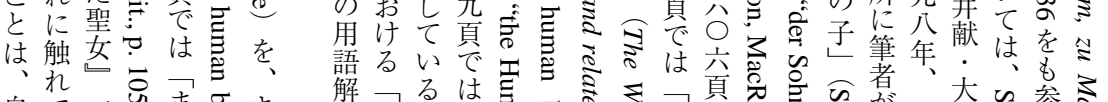
自て兄ま官 キ 分次六な゙こ志 ン 内上頁:のとは にうでき人と前

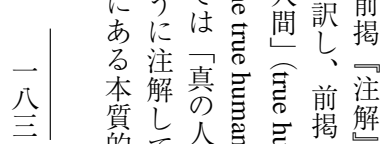
質し人忍导揭解 ない間奇. 总四

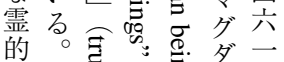

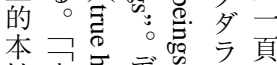

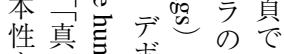
をの灵とマは 見人問儿訳少真

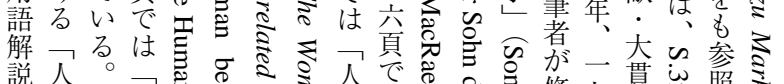
説人

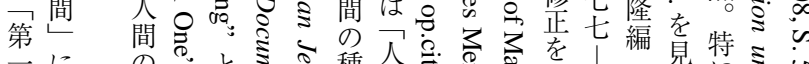
のに

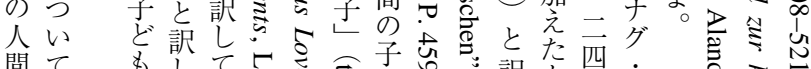

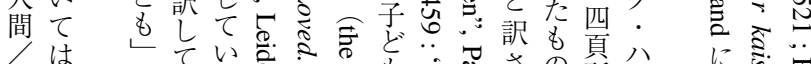
完 全 前 な揭 るっ 間グ 真六 真八

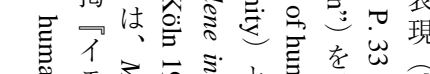

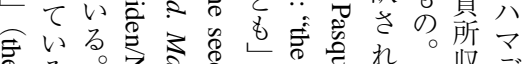

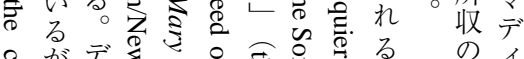

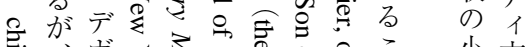

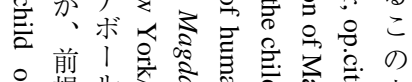

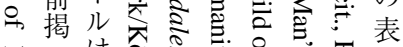

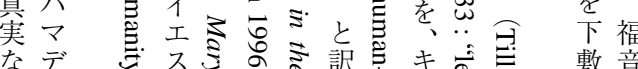
小文专菩

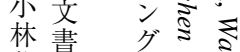
訳 II 提窎 敷音対密豆 


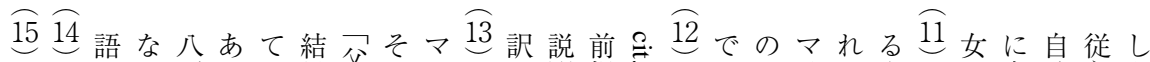

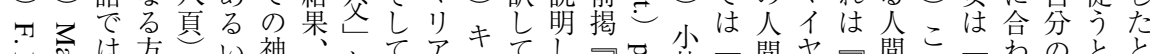

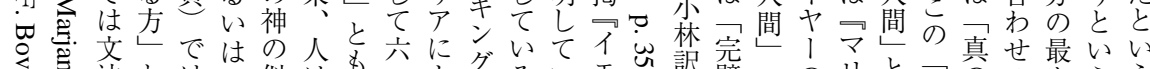

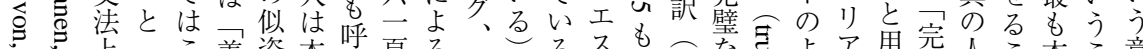

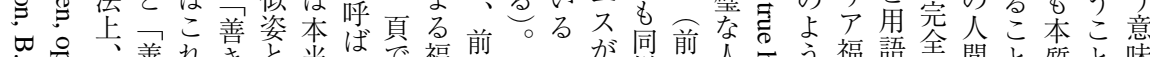

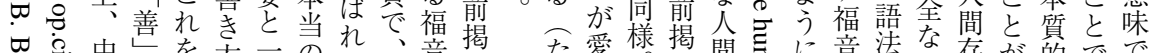

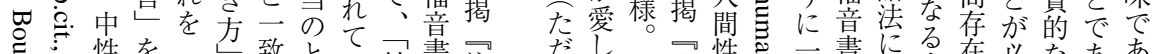

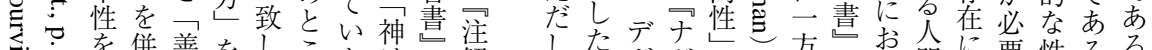
す者僧善をしたるなは解

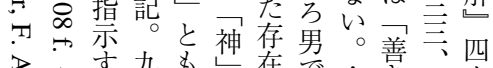

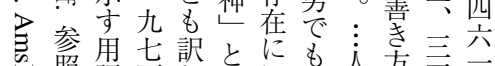

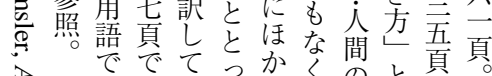

市ばてっから少と頁

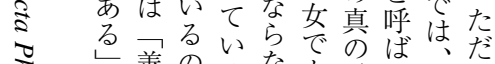

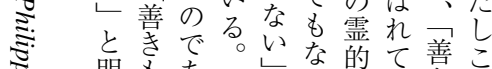

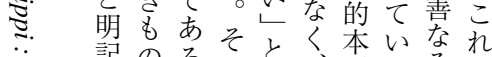

矛記のろの説超質るるる

言訳八施越性過と前

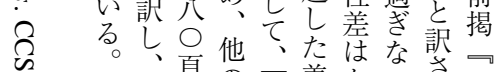

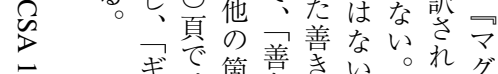

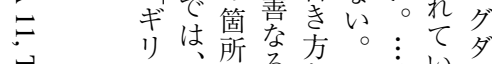

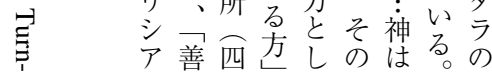

したデ聚ボ方热間在要性るる

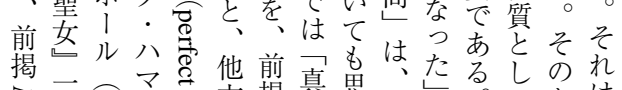

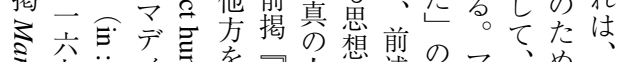

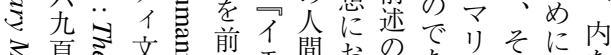

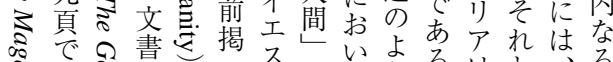

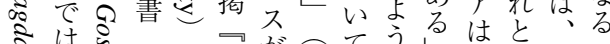

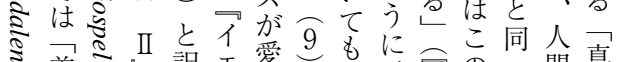

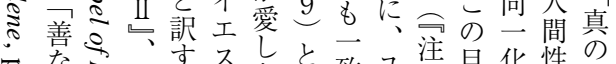

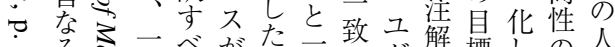

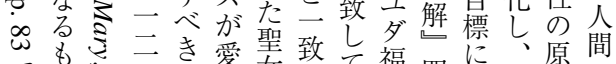
でのし二元怒守て福四到モ型の はレ条はた頁はる童六達デ的種

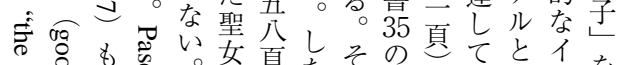

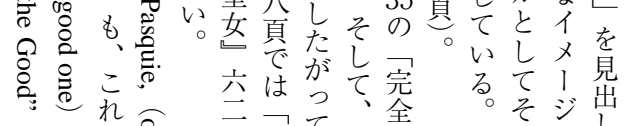
ととを照頁てこ真彼机をし

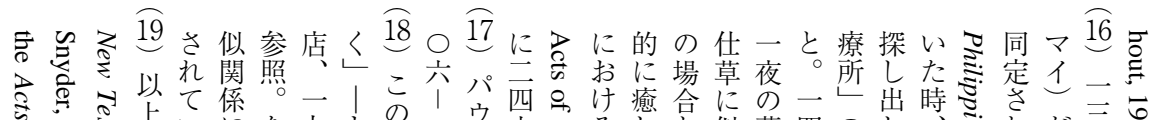

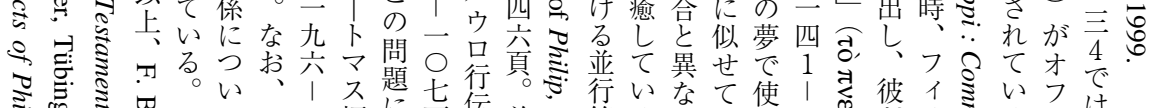

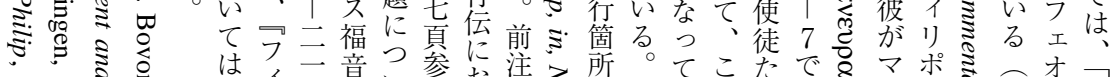

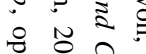
‥ 요

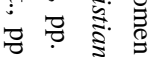

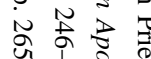

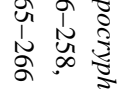

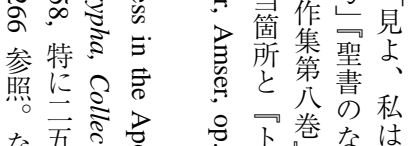

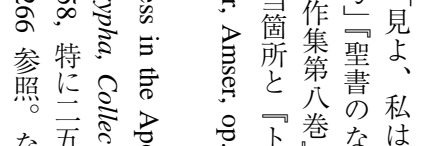

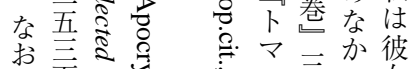

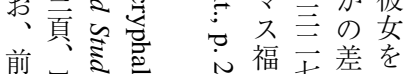
前了煎要 福王差を 拼黄要

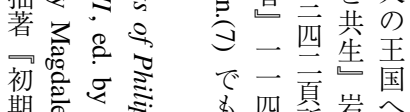
者豆灾

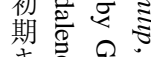
も四頁岩 $\frown$

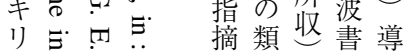

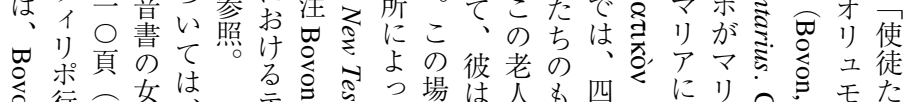
朰行前女は 伝前性拙 目. 著再論

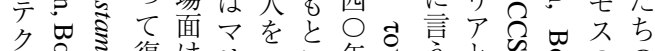

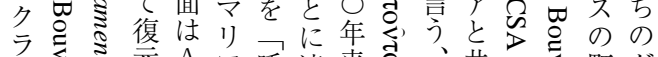

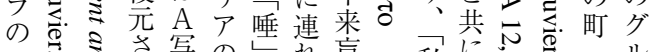

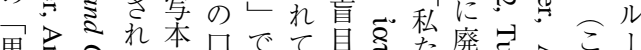

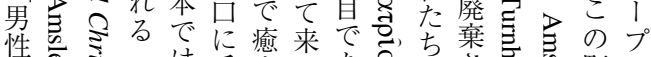

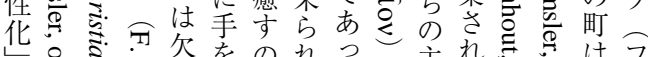

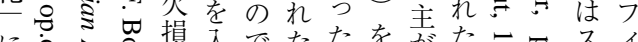

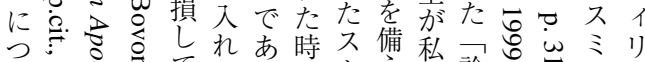

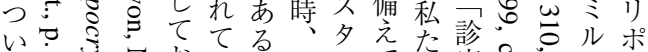

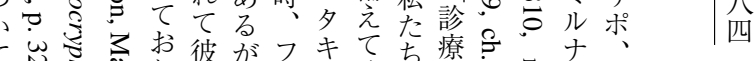

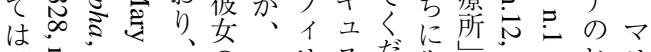

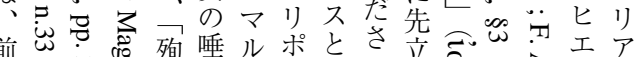

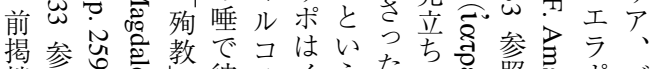

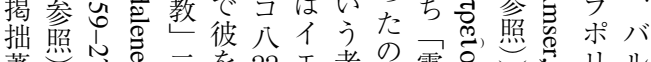

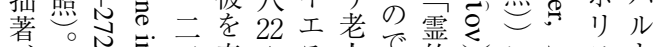

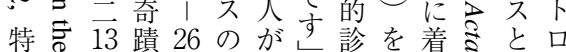




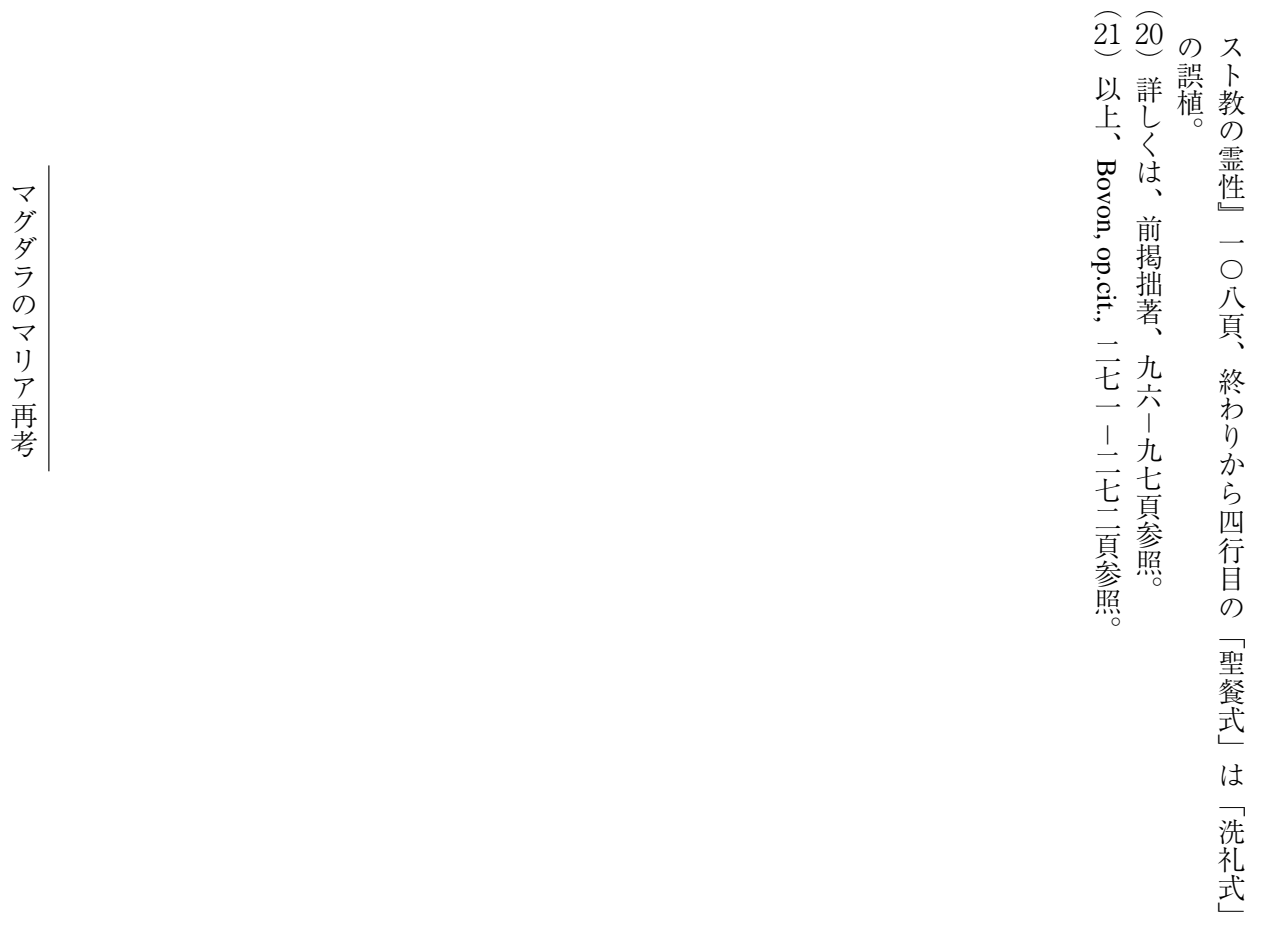


What Is Gnosticism? Cambridge/London, 2003, pp. 218ff.)

It is true that the term "Gnosticism" or "Gnostizismus" derives from the French word "gnositicisme", which in turn was created in the $18^{\text {th }}$ century from the word "Gnosis", which had derogatory connotations. However, the concept of "Gnosis" was an important keyword to the religious thinking of early Christianity and its fringes in the $2^{\text {nd }}$ to $3^{\text {rd }}$ centuries $\mathrm{AD}$. More specifically, it represented the salvation of "knowledge" founded on "anticosmic dualism", wherein mankind's "Original Self" was the basis of the "Perfect Human", which was equivalent to the "Highest God". Pastoral epistles had already been using the phrase "what is falsely called knowledge (gnōsis)" (1 Tim 6:20), and Polemicists beginning with Irenaeus employed the term negatively to contrast it with the "true gnōsis" of the Church. Of course, their refutation of "falsely called gnōsis" was based in part on their misinterpretation of the precepts constituting "gnōsis". Neither can we count those writings - nor the "Gospel according to Mary" and the "Act of Philip"- as elements of "Gnosticism". However, we also cannot deny that those who defined "Gnosis" with the aforementioned meanings of mankind's salvation called themselves "Gnostics" (or gnōstikoi). (See also K. Rudolph, Die Gnosis. Wesen und Geschichte einer spaetantiken Religion, 3. Aufl., Göttingen, 1994, S. 220f. ; H.-F. Weiss, Frühes Christentum und Gnosis, Tübingen. Eeine rezeptionsgeschichtliche Studie, Tübingen, 2008, S. 42f., 54 ; B. Aland, Was ist Gnosis? Studien zum Christentum, zu Markion und zur kaiserzeitlichen Philosophie, Tübingen, 2009, S. 3f.)

As such, this essay's conclusion is as follows. Mary Magdalene was estimated highly in the peripheries of early Christianity - by some elements of Gnosticism, the boundary between those groups and early Catholicism, and by a portion of Christian asceticism (Encratism) - as the leader or at least a member of the Apostles. 


\section{Mary Magdalene Reconsidered : Her Location in Earliest Christianity}

Sasagu ARAI, M. J. A.

During the establishment of early Catholicism, Mary Magdalene - the leader of the women who accompanied Christ's missionary travels (Luke $8: 1-3$ )-was mistakenly identified as "a woman, who was a sinner" (Luke $7: 37$ ) and subsequently labeled the prototype of the "sinner, who is to repent". By contrast, Gnosticism-which had been criticized as heretical by the Polemicists, who represented early Catholicism-viewed her as the prototype of mankind's "Original Self". Gnosticism saw Mary as Christ's "beloved woman disciple" or "companion", placing her on an even higher plane than Peter, whom early Catholicism had named the foundation of the apostolic tradition and the bearer of the "Canon of the Faith" (regular fidei).

However, Gnosticism was not alone in putting Mary on this elevated pedestal. The "Gospel according to Mary", which is located in the gray zone between early Catholicism and Gnosticism, relates how Christ secretly communicated his words to Mary. As such, it, too, can be seen as placing Mary above Peter as Christ's messenger.

We can also observe Mary's vaunted position in the "Act of Philip", which is thought to be based on Christian asceticism (Encratism) that is completely unrelated to Gnosticism. In this Act, Mary - along with Philip and Bartholomew engages in missionary work as one of the Apostles. She performs miracles of healing with Philip, and even carries out baptisms.

Of course, K. L. King, echoing M. A. William's rethinking and problematization of Gnosticism (Rethinking "Gnosticism: An Argument for Dismantling a Dubious Category, Princeton 1996), posits: "But there was no religion in antiquity called Gnosticism. Scholars invented the term in the process of categorizing the variety of early Christian heresies." (The Gospel Mary of Magdala. Jesus and the First Women Apostle, Santa Rosa, 2003, p. 155. See also 